\title{
Adsorbsi Zat Warna Alami Buah Mangrove Jenis Rhizophora Stylosa dan Kulit Kayu Tingi ke Dalam Kain dengan Pengunci Tunjung dan Tawas
}

\author{
Paryanto $^{1}$, Ayu Mustika Wijaya ${ }^{2}$, Dwi Bagas Ongko Widodo ${ }^{3}$, Sonia Waluya ${ }^{4}$, Wahyu Daut \\ Utomo $^{5 *}$
}

1 Program Studi Sarjana Teknik Kimia, Fakultas Teknik, Universitas Sebelas Maret

E-mail: aparyanto.uns@gmail.com

\begin{abstract}
The textile industry in Indonesia is growing rapidly, this is confirmed by Badan Pusat Statistik (BPS) which shows that the production of the clothing industries have a significant growth of 15.29 percent in 2019. The use of textile dyes will cause waste problems in the environment. So we need natural dyes as a safer and environmentally friendly alternative. The purpose of this study was to obtain data analysis and to determine the adsorption equilibrium constant value of the natural dye of mangrove Rbizophora stylosa and tingi bark with variations in the amount of dyeing in primisima cloth by comparing it with the Langmuir and Freundlich equations and knowing the role of tunjung and alum in the process of fixing dyes into cloth. This study used a solid-liquid extraction method and then tested by spectrophotometry to obtain initial concentration data. Next, pour the dye that has been tested for its tannin content into a measuring cup and insert the cloth as a medium for mass transfer of tannins from liquid to solid. Samples were taken for each dyeing and tested for tannin content by spectrophotometry and the $\mathrm{Ca}$ value was obtained. The adsorption test for the absorption process of tannins in natural dyes by cloth was carried out by calculating using the Langmuir and Freundlich equation. Furthermore, the cloth that has been dyed is fixed by tunjung and alum. The most suitable determination of the adsorption equilibrium constant of the cloth against natural dyes Rhizopora stylosa and tingi bark is by using the Freundlich adsorption equation compared to the Langmuir equation. This is evidenced by the error value of the Freundlich equation is smaller than the Langmuir equation by showing the value of $\mathrm{R}^{2}$ which is close to 1 . The adsorption equilibrium constant value of the Langmuir equation tingi bark for three,five, and seven times of dyeing obtained is $0.00517,0.00421$ and 0.003899 . Whereas in the Freundlich equation for tingi bark for three, five and seven times of dyeing, the adsorption equilibrium constant value is $0.4312,0.30114$ and 0.2424 . The adsorption equilibrium constant value of the Langmuir Rhiropora stylosa equation for three, five and seven times of dyeing is $0.005224,0.004415$ and 0.00408 . Whereas in the Freundlich equation for Rhizopora stylosa for three, five and seven times of dyeing is $0.3862,0.2733$ and 0.2126 . It can be concluded that the more dyeing, the less the absorbency of the cloth on tannins. The color change of fixation the cloth in the dyeing of Rhiropora stylosa extract with tunjung is from brown to grayish brown, while with alum from brown to dark brown. The color change of fixation the cloth in the dyeing of tingi bark extract with alum is from brown to black, while with alum from brown to dark brown.
\end{abstract}

Keywords: adsorption, fixation, Rbizophora stylosa, tannin, tingi bark

EQUILIBRIUM Volume 5 No.1 July 2021

Online at http://equilibrium.ft.uns.ac.id 


\section{Pendahuluan}

Industri di Indonesia mengalami perkembangan yang sangat pesat khususnya di bidang industri tekstil, hal tersebut diperkuat dari data Badan Pusat Statistik (BPS) yang menunjukkan bahwa produksi industri pakaian mengalami pertumbuhan signifikan sebesar 15,29 persen pada tahun 2019 [8]. Industri ini memberikan pengaruh positif di dalam negeri berupa meningkatnya perekonomian nasional. Salah satu bahan yang erat dengan industri tekstil adalah pewarna sintetis. Pewarna sintesis memiliki beberapa kelebihan di antaranya mudah didapat, pilihan warna, dan kemudahan penggunaan. Namun, proses pembuatan pewarna ini seringkali berbahaya bagi kesehatan dan lingkungan dikarenakan hasil limbah dari industri tekstil pada umumnya termasuk dalam kategori limbah B3 (bahan berbahaya dan beracun) yang mengandung logam berat, seperti logam, fenol, senyawa organik toksik, fosfat, kadmium, dan besi [5] . Oleh karena itu, ada peluang untuk memperkenalkan kembali pewarna alami sebagai alternatif yang lebih aman dan ramah lingkungan.

Zat pewarna alam sejak dahulu telah digunakan sebagai pewarna batik dan sampai saat ini pewarna alami untuk batik paling aman dibandingkan pewarna sintetis/kimia. Zat pewarna alami asal tumbuhtumbuhan maupun hewan, bentuk dan kadarnya berbeda-beda, hal ini dipengaruhi oleh faktor-faktor jenis tumbuhan seperti iklim, tanah, umur, dan faktor-faktor lainnya [6]. Keunggulan dari proses pewarnaan menggunakan pewarna alami adalah sifatnya yang ramah lingkungan [16]. Salah satu bahan alam yang dapat digunakan sebagai bahan pewarna alami pengganti pewarna sintetis adalah buah mangrove spesies Rhirophora stylosa [12]. Bahan lainnya yang juga dapat digunakan sebagai bahan pewarna alami pengganti pewarna sintetis selain buah mangrove yaitu kulit kayu tingi

Mangrove adalah tumbuhan yang banyak dijumpai pada garis pantai datar, muara, delta, dan kawasan pantai yang dilindungi dan daerah pasang surut air laut. Berdasarkan data dari Kementerian Lingkungan Hidup dan Kehutanan, luas hutan mangrove di Indonesia pada tahun 2020 mencapai 3,48 juta Ha (tahun 2015) dimana merupakan ekosistem mangrove terluas di dunia Mangrove jenis Rhizopora stylosa biasa digunakan untuk bahan baku pembuatan arang, kayu bakar, pewarna, obat, dan makanan. Mangrove merupakan salah satu bahan yang dapat dijadikan sebagai zat warna alami dalam pembatikan karena mangrove mengandung tanin. [7]

. Soga tingi merupakan salah satu sumber daya alam dari jenis mangrove yang banyak tumbuh di berbagai daerah di Indonesia, soga tingi merupakan sumber tanin yang dapat digunakan sebagai bahan penyamak[17].Kulit soga tingi (Ceriops tagal) dapat menghasilkan tanin dari 13\% sampai lebih dari 40\%. Tanin ini termasuk ke dalam kelompok tanin terkondensasi tipe proyanidin, sehingga pewarnaan dengan kulit pohon soga tingi memberikan warna coklat kemerahan [2]. Selain bisa dimanfaatkan sebagai pewarna, soga tingi juga bisa digunakan sebagai bahan penyamak nabati karena kandungan tanin yang tinggi. Tanin dapat dipisahkan dari padatannya dengan metode ekstraksi [15]. Ekstraksi propagul mangrove dapat dilakukan dengan metode konvensional dan non konvensional. Ekstraksi secara konvensional yang pernah dilakukan yaitu ekstraksi dengan soxhletasi. Proses tersebut cukup memiliki efektifitas dan efisiensi yang tinggi, namun memerlukan waktu yang lebih lama [3].

Tanin adalah senyawa polifenol alami dengan gugus hidroksil fenolik yang memungkinkannya untuk membentuk ikatan silang yang efektif antara protein dan makromolekul lainnya. Tanin merupakan zat alami yang dihasilkan oleh buah mangrove yang memberi rasa getir[14]. Nilai absorpsi maksimum yang diperoleh pada panjang gelombang antara 300 dan $550 \mathrm{~nm}$ menunjukkan transisi $\mathrm{C}=\mathrm{C}$ dan $\mathrm{C}=\mathrm{O}$. Ikatan terkonjugasi $\mathrm{C}=\mathrm{C}$ dan $\mathrm{C}=\mathrm{O}$ terdapat pada gugus kromofor, yang mendukung asumsi bahwa warna coklat hasil ekstraksi disebabkan oleh adanya kandungan tanin [9]. Tanin umumnya didapatkan dengan ekstraksi dari tanaman. Kulit pohon bakau yang dikeringkan atau dihancurkan dan dibuat menjadi tepung rata-rata mengandung tanin $20-30 \%$ dan kadar tanin tersebut tergolong cukup tinggi. [4]. Tujuan dari ekstraksi tanin adalah terdifusinya sejumlah gugus fenol yang terkandung dalam material tanaman menuju fase cair. Hasil ekstrak tanin yang terekstrak harus segera dianalisis kadarnya [11].

Penelitian ini bertujuan untuk mendapatkan dan menganalisis data konstanta kesetimbangan adsorpsi antara larutan tanin Rhizophora stylosa dan kulit kayu tingi dengan kain primisima pada variasi jumlah pencelupan kain terhadap zat warna, lalu membandingkan data kesetimbangan adsorpsi antara persamaan Langmuir dan Freundlich, serta mengetahui peranan pengunci tunjung dan tawas dalam kain yang telah dicelupkan oleh zat warna Rhizophora stylosa dan kulit kayu tingi. 


\section{Metode}

\subsection{Bahan}

Buah mangrove Rhizophora stylosa dan kulit kayu tingi diperoleh dari PT. Pertamina ,Cilacap,Jawa Tengah. Tunjung dan tawas diperoleh dari toko Santoso Pasar Klewer, Surakarta. Kain primisima diperoleh dari toko kain Mac Mohan Jl. Gatot Subroto No. 42, Kemlayan, Surakarta.

\subsection{Alat}

Alat utama yang digunakan adalah ekstraktor zat warna alam dan alat analisis zat warna alam spektrofotometer UV-Vis Double Beam seri UV-1601 PC,

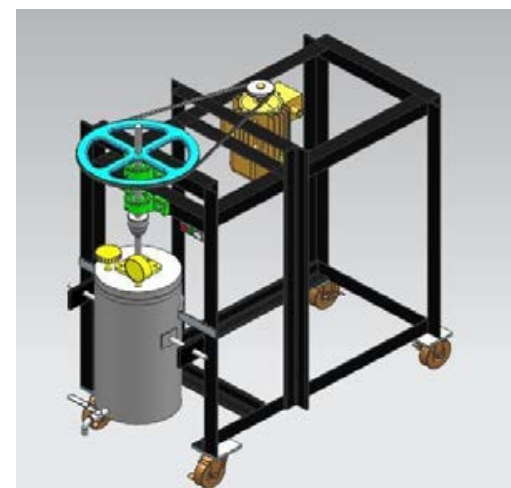

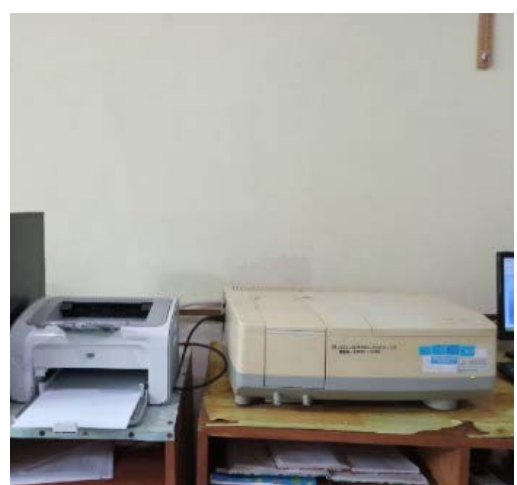

b.

Gambar 1. Rangkaian Alat Ekstraktor (a), Spektrofotometer UV-Vis Double Beam seri UV-1601 PC (b)

Alat pendukung yang digunakan adalah ember, pengaduk, gelas beaker $100 \mathrm{~mL}$, pipet volume.

\subsection{Cara kerja}

Langkah pertama yaitu menyiapkan bahan baku. Buah mangrove dan kulit kayu tingi dikeringkan terlebih dahulu dengan cara dijemur hingga benar-benar kering ditandai dengan perubahan warna dari hijau menjadi hitam. Setelah kering buah mangrove ditumbuk hingga halus atau memperkecil ukurannya agar ekstraksi yang dilakukan berjalan optimal. Kemudian menyiapkan kain primisima yang dipotong dengan ukuran $40 \mathrm{~cm}$ x 40 $\mathrm{cm}$. Selanjutnya kain ditimbang sebelum dan sesudah pencelupan.

Langkah kedua yaitu mengekstraksi zat warna dari mangrove Rhizopora Stylosa dan kulit kayu tingi. dengan cara memasukkan bahan Rhizopora stylosa yang telah dikeringkan ke dalam alat ekstraktor sebanyak 1 kg kemudian ditambahkan air sebanyak 7 liter ke dalam alat ekstraktor tersebut. Kemudian dilanjutkan mengekstrak bahan dengan menyalakan pemanas kompor selama 1 jam dengan suhu 80-90 ${ }^{\circ}$ C. Setelah 1 jam hasil ekstraksi disaring untuk memisahkan ampas dengan ekstrak zat warna Rhizopora stylosa.. Hal yang sama dilakukan untuk ekstraksi kayu tingi.

Langkah ketiga yaitu mordanting kain primisima. Pertama melarutkan $1 \mathrm{~kg}$ tawas dalam air sebanyak 5 liter dengan cara direbus hingga larut sempurna. Kemudian larutan ditambahkan air sebanyak 10 liter dan diaduk hingga homogen, maka kain primisima siap untuk mordanting dengan cara mencelupkan kain ke dalam larutan tersebut selama 10 menit. Setelah itu kain dijemur hingga kering untuk siap dicelupkan ke dalam zat warna.

Setelah tahap mordanting kain dilanjutkan ke tahap pencelupan kain ke dalam zat warna. Pertama masukkan ekstrak zat warna mangrove Rhizopora stylosa kedalam gelas beker sebanyak $100 \mathrm{~mL}$ yang telah dianalisis kadar tanin awalnya (C). Kemudian mencelupkan kain yang telah ditimbang ke dalam zat warna tersebut selama 10 menit. Setelah pencelupan, kain dikeringkan dengan cara di biarkan di udara terbuka sampai kain kering. Selain itu larutan yang digunakan untuk pencelupan diambil sebanyak $20 \mathrm{~mL}$ untuk dianalisis kadar taninnya (Ce). Setelah kain kering dilakukan penimbangan kain untuk mengetahui massa kain (m). Begitu juga untuk pencelupan kayu tingi dilakukan hal yang sama dengan pencelupan kedalam ekstrak kulit kayu tingi 
Tahap terakhir yaitu penguncian kain dengan pengunci tunjung dan tawas. Pertama memasukkan 1 $\mathrm{kg}$ tawas atau tunjung ke dalam ember. Setelah itu masukan $10 \mathrm{~L}$ air dan mengaduknya hingga homogen. Terakhir masukan kain kering yang telah dicelupkan zat warna ke dalam larutan tawas atau tunjung.

\subsection{Analisis Hasil}

Hasil ekstraksi dari buah mangrove jenis Rhizophora stylosa dan kulit kayu tingi dianalisis kadar tanin untuk menentukan konstanta kesetimbangan adsorbsi. Analisis kadar tanin buah mangrove dengan membandingkan hasil percobaan dengan larutan tanin standar (asam tanat) yang sudah dibeli di pasaran. Tanin standar yang sudah dibeli di pasaran dibuat larutan dengan kadar antara 0 hingga 100 ppm $(1 \mathrm{ppm}=$ $1 \mathrm{mg} / \mathrm{L}$ air) dengan interval $10 \mathrm{dan}$ di cek adsorbansinya pada panjang gelombang $745 \mathrm{~nm}$ [10]. Setelah dilakukan pengecekan terhadap adsorbansi dibuat kurva larutan tanin standar.

Setelah kadar tanin diketahui, selanjutnya menentukan konstanta kesetimbangan adsorbsi dengan menggunakan persamaan Langmuir dan Freundlich yang telah disusun, kemudian dilakukan perhitungan secara numeris menggunakan program Microsoft Excel. Data diambil dari hasil percobaan ekstraksi tanin dari buah mangrove (Rhizophora stylosa) dan kulit kayu tingi. Nilai konstanta kesetimbangan adsorbsi optimum dapat dicari dengan membandingkan hasil perhitungan antara persamaan Langmuir dan persamaan Freundlich.

\section{Hasil dan Pembahasan}

\subsection{Pembuatan Larutan Standar (Cao)}

Tanin standar yang diperoleh di pasaran dibuat larutan standar dengan konsenstrasi antara 10 - 100 ppm kemudian diuji nilai adsorbansinya menggunakan spektrofotometer pada panjang gelombang $745 \mathrm{~nm}$ [9]. Hasil data yang diperoleh dari analisa kadar tanin standar kemudian dibuat grafik seperti terlihat pada gambar dibawah ini

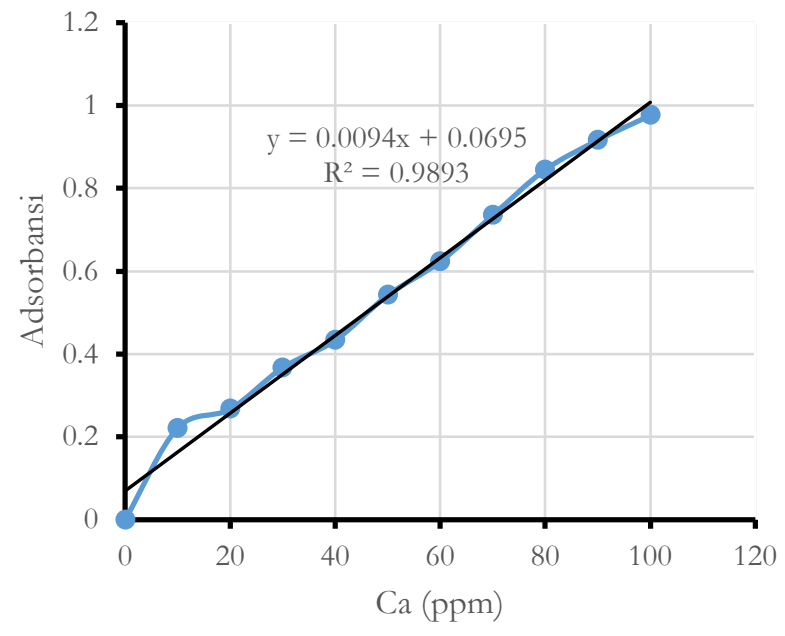

Gambar 2 Kurva Standar Larutan Asam Tanat

Zat warna yang telah dihasilkan dianalisa kandungan taninnya diperoleh data untuk buah mangrove jenis Rhizophora stylosa adsorbansinya sebesar 3,612, sedangkan untuk kulit kayu tingi sebesar 4,000 kemudian data adsorbansi dihubungkan dengan grafik larutan standar tanin diatas dan diperoleh data kandungan tanin yang ada pada zat warna buah mangrove sebesar 376,682 ppm dan kulit kayu tingi sebesar 418,318 ppm.

\subsection{Penentuan Nilai Kesetimbangan Adsorbsi}

Data yang telah didapatkan dari data penelitian dapat digunakan untuk menentukan nilai kesetimbangan adsorbsi.. Pengujian pola isoterm adsorbsi yang sesuai untuk proses penyerapan tanin pada zat warna alami oleh kain dilakukan dengan perhitungan menggunakan persamaan Langmuir dan Freundlich. 


\subsubsection{Model Langmuir}

Model Langmuir didasarkan pada penyerapan satu lapisan, sehingga kapasitas permukaan untuk penyerapan ada nilai maksimumnya (terbatas). Uji persamaan Langmuir dilakukan dengan menggunakan persamaan 1 [1]:

Dimana

$$
\frac{m \cdot C e}{X m}=\frac{C e}{b}+\frac{1}{k b}
$$

m : massa kain setelah pencelupan (gram)

Ce : konsentrasi zat terlarut dalam larutan setelah tercapai kesetimbangan adsorpsi (ppm)

Xm : Berat tanin terserap $(\mathrm{mg})$

b : Kapasitas adsorbsi (mg/g)

k : Konstanta Langmuir

\subsubsection{Kulit kayu tingi}

Larutan zat warna alami yang telah diketahui konsentrasinya kemudian dimasukkan ke gelas beaker sebanyak $100 \mathrm{~mL}$. Kain yang telah ditimbang dimasukkan ke dalam gelas beaker yang sudah terisi $100 \mathrm{~mL}$ larutan zat warna. Setiap pencelupan diambil sampel untuk diuji nilai adsorbansinya sehingga dapat dianalisis konsentrasinya.

Tabel 1. Data - data untuk Persamaan Langmuir pada Tiga Kali Pencelupan untuk Kulit Kayu Tingi

\begin{tabular}{cccccccc} 
No. & $\begin{array}{c}\text { Tanin } \\
\text { awal } \\
(\mathrm{ppm})\end{array}$ & $\begin{array}{c}\text { Tanin } \\
\text { setimbang } \\
(\mathrm{ppm})\end{array}$ & $\begin{array}{c}\text { Tanin } \\
\text { teradsorbsi } \\
(\mathrm{ppm})\end{array}$ & $\begin{array}{c}\mathrm{V} \\
\text { larutan } \\
(\mathrm{L})\end{array}$ & $\begin{array}{c}\text { Massa } \\
\text { kain } \\
(\mathrm{gram})\end{array}$ & $\begin{array}{c}\mathrm{Xm} / \mathrm{m} \\
(\mathrm{mg} / \mathrm{gr})\end{array}$ & Ce/(Xm/m) \\
\hline 1 & 418,138 & 253,883 & 164,255 & 0,1 & 17,096 & 0,961 & 264,246 \\
2 & 418,138 & 275,904 & 142,234 & 0,1 & 17,622 & 0,807 & 341,830 \\
3 & 418,138 & 301,223 & 116,915 & 0,1 & 18,083 & 0,647 & 465,896 \\
\hline
\end{tabular}

Tabel 2. Data - data untuk Persamaan Langmuir pada Lima Kali Pencelupan untuk Kulit Kayu Tingi

\begin{tabular}{cccccccc}
\hline No. & $\begin{array}{c}\text { Tanin } \\
\text { awal } \\
(\mathrm{ppm})\end{array}$ & $\begin{array}{c}\text { Tanin } \\
\text { setimbang } \\
(\mathrm{ppm})\end{array}$ & $\begin{array}{c}\text { Tanin } \\
\text { teradsorbsi } \\
(\mathrm{ppm})\end{array}$ & $\begin{array}{c}\mathrm{V} \\
\text { larutan } \\
(\mathrm{L})\end{array}$ & $\begin{array}{c}\text { Massa } \\
\text { kain } \\
(\mathrm{gram})\end{array}$ & $\begin{array}{c}\mathrm{Xm} / \mathrm{m} \\
(\mathrm{mg} / \mathrm{gr})\end{array}$ & Ce/(Xm/m) \\
\hline 1 & 418,138 & 253,883 & 164,255 & 0,1 & 17,434 & 0,942 & 269,470 \\
2 & 418,138 & 275,904 & 142,234 & 0,1 & 17,793 & 0,799 & 345,147 \\
3 & 418,138 & 301,223 & 116,915 & 0,1 & 18,036 & 0,648 & 464,685 \\
4 & 418,138 & 338,245 & 79,894 & 0,1 & 18,638 & 0,429 & 789,075 \\
5 & 418,138 & 367,606 & 50,532 & 0,1 & 18,730 & 0,270 & 1362,558 \\
\hline
\end{tabular}

Tabel 3. Data - data untuk Persamaan Langmuir pada Tujuh Kali Pencelupan untuk Kulit Kayu Tingi

\begin{tabular}{cccccccc}
\hline No. & $\begin{array}{c}\text { Tanin } \\
\text { awal } \\
(\mathrm{ppm})\end{array}$ & $\begin{array}{c}\text { Tanin } \\
\text { setimbang } \\
(\mathrm{ppm})\end{array}$ & $\begin{array}{c}\text { Tanin } \\
\text { teradsorbsi } \\
(\mathrm{ppm})\end{array}$ & $\begin{array}{c}\mathrm{V} \\
\text { larutan } \\
(\mathrm{L})\end{array}$ & $\begin{array}{c}\text { Massa } \\
\text { kain } \\
(\mathrm{gram})\end{array}$ & $\begin{array}{c}\mathrm{Xm} / \mathrm{m} \\
(\mathrm{mg} / \mathrm{gr})\end{array}$ & $\mathrm{Ce} /(\mathrm{Xm} / \mathrm{m})$ \\
\hline 1 & 418,138 & 253,883 & 164,255 & 0,1 & 17,183 & 0,956 & 265,591 \\
2 & 418,138 & 275,904 & 142,234 & 0,1 & 17,722 & 0,803 & 343,770 \\
3 & 418,138 & 301,223 & 116,915 & 0,1 & 18,105 & 0,646 & 466,463 \\
4 & 418,138 & 338,245 & 79,894 & 0,1 & 18,691 & 0,427 & 791,319 \\
5 & 418,138 & 367,606 & 50,532 & 0,1 & 18,558 & 0,272 & 1350,046 \\
6 & 418,138 & 376,862 & 41,277 & 0,1 & 19,172 & 0,215 & 1750,433 \\
7 & 418,138 & 389,734 & 28,404 & 0,1 & 19,071 & 0,149 & 2616,727 \\
\hline
\end{tabular}

Adsorbsi Zat Warna Alami Buah Mangrove Jenis Rhizophora Stylosa dan Kulit Kayu 
Tabel .1 menunjukkan jumlah tanin kulit kayu tingi yang teradsorbsi oleh kain pada tiga kali pencelupan. Tabel ini menunjukkan bahwa semakin banyak pencelupan yang dilakukan maka berat kain akan semakin bertambah. Pada satu kali pencelupan berat kain 17,096 gram dan pada tiga kali pencelupan beratnya menjadi 18,033 gram. Berbeda dengan tanin yang teradsorbsi ke dalam kain, dari satu kali sampai pencelupan ke tiga didapat tanin yang teradsorbsi semakin kecil. Pada pencelupan pertama tanin yang teradsorbsi sebesar $164,255 \mathrm{ppm}$ atau $0,961 \mathrm{mg} / \mathrm{gr}$ kain sedangkan pada pencelupan ke tiga 116,915 ppm atau 0,647 mg/gr kain. Hal itu terjadi karena kain mulai jenuh jika dilakukan pencelupan terus menerus dengan berat kain akan konstan karena kain memiliki kemampuan terbatas dalam menyerap zat warna.

Tabel .2 merupakan tabel jumlah tanin kulit kayu tingi yang teradsorbsi oleh kain pada lima kali pencelupan. Tabel ini menunjukkan bahwa semakin banyak pencelupan yang dilakukan maka berat kain akan semakin bertambah. Pada satu kali pencelupan berat kain 17,434 gram dan pada lima kali pencelupan beratnya menjadi 18,730 gram. Berbeda dengan tanin yang teradsorbsi ke dalam kain, dari pencelupan pertama sampai pencelupan ke lima didapat tanin yang teradsorbsi semakin kecil. Pada pencelupan pertama tanin yang teradsorbsi sebesar 164,255 ppm atau $0,942 \mathrm{mg} /$ gram kain sedangkan pada pencelupan ke lima 50,532 ppm atau $0,27 \mathrm{mg} /$ gram kain. Hal itu terjadi karena kain mulai jenuh jika dilakukan pencelupan terus menerus berat kain akan konstan karena kain memiliki kemampuan terbatas dalam menyerap zat warna.

Tabel .3 merupakan tabel jumlah tanin kulit kayu tingi yang teradsorbsi oleh kain pada tujuh kali pencelupan. Tabel ini menunjukkan bahwa semakin banyak pencelupan yang dilakukan maka berat kain akan semakin bertambah. Pada satu kali pencelupan berat kain 17,722 gram dan pada tujuh kali pencelupan beratnya menjadi 19,071 gram. Berbeda dengan tanin yang teradsorbsi ke dalam kain, dari pencelupan pertama sampai pencelupan ke tujuh didapat tanin yang teradsorbsi semakin kecil. Pada pencelupan pertama tanin yang teradsorbsi sebesar 164,255 ppm atau $0,956 \mathrm{mg} / \mathrm{gram}$ kain sedangkan pada pencelupan ke tiga 28,404 ppm atau 0,149 mg/gram kain. Hal itu terjadi karena kain mulai jenuh jika dilakukan pencelupan terus menerus berat kain akan konstan karena kain memiliki kemampuan terbatas dalam menyerap zat warna.
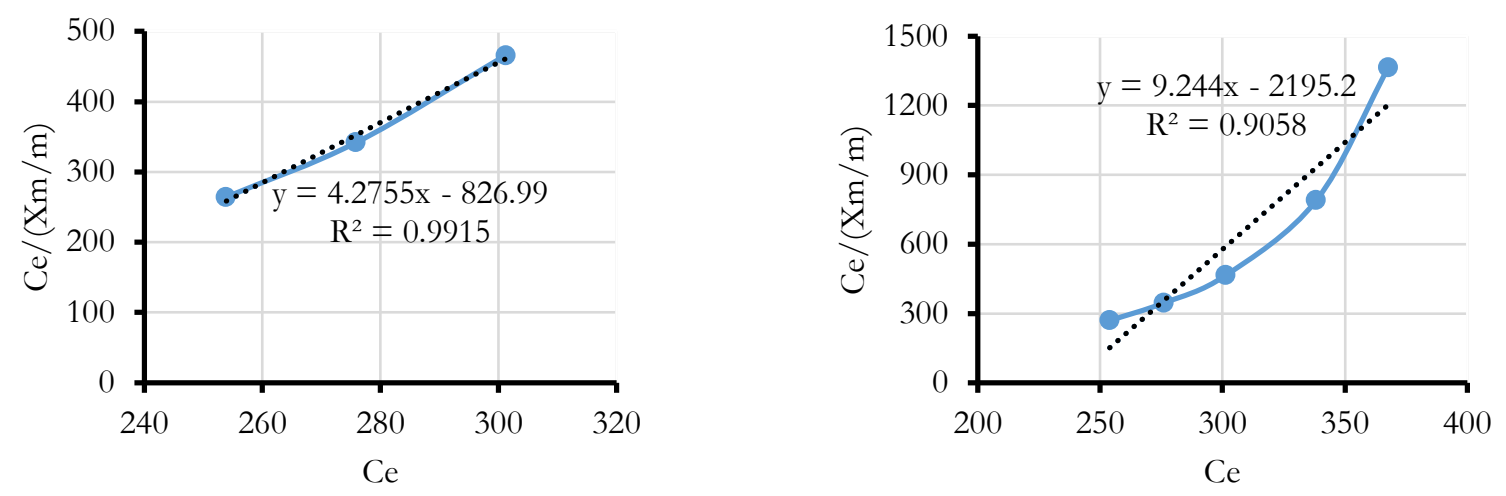

a.

$\mathrm{b}$

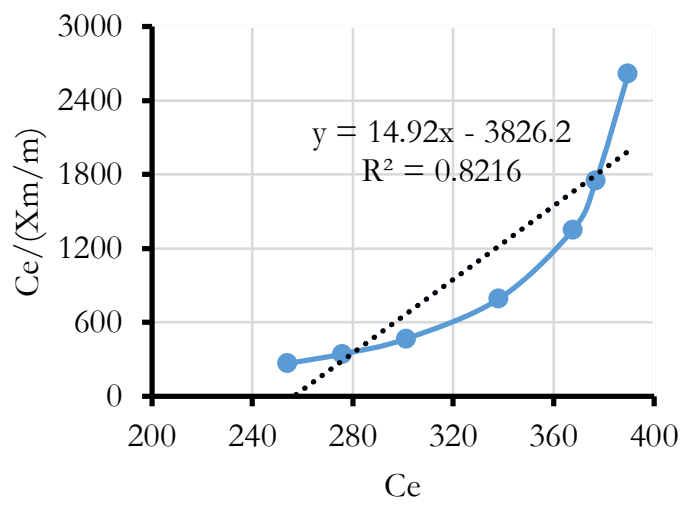

c.

Gambar 2. Tiga Kali Pencelupan (a), Lima Kali Pencelupan (b), Tujuh Kali Pencelupan (c) 
Berdasarkan persamaan pada grafik tiga kali pencelupan diperoleh nilai b sebesar 0,2338 $\mathrm{mg} / \mathrm{gr}$ dan nilai $\mathrm{k}$ sebesar 0,00517. Untuk lima kali pencelupan diperoleh nilai b sebesar $0,10817 \mathrm{mg} / \mathrm{gr}$ dan nilai $\mathrm{k}$ sebesar 0,00421. Untuk Tujuh kali pencelupan diperoleh nilai b sebesar $0,0670 \mathrm{mg} / \mathrm{gr}$ dan nilai $\mathrm{k}$ sebesar 0,003899 .

\subsubsection{Buah Mangrove jenis Rhizophora Stylosa}

Larutan zat warna alami yang telah diketahui konsentrasinya kemudian dimasukkan ke gelas beaker sebanyak $100 \mathrm{~mL}$. Kain yang telah ditimbang dimasukkan ke dalam gelas ukur yang sudah terisi $100 \mathrm{~mL}$ larutan zat warna. Setiap pencelupan diambil sampel untuk diuji nilai adsorbansinya sehingga dapat dianalisis konsentrasinya.

Tabel 4. Data - data untuk Persamaan Langmuir pada Tiga Kali Pencelupan untuk Buah Mangrove Jenis Rhizophora stylosa

\begin{tabular}{cccccccc} 
No. & $\begin{array}{c}\text { Tanin } \\
\text { awal } \\
(\mathrm{ppm})\end{array}$ & $\begin{array}{c}\text { Tanin } \\
\text { setimbang } \\
(\mathrm{ppm})\end{array}$ & $\begin{array}{c}\text { Tanin } \\
\text { teradsorbsi } \\
(\mathrm{ppm})\end{array}$ & $\begin{array}{c}\mathrm{V} \\
\text { larutan } \\
(\mathrm{L})\end{array}$ & $\begin{array}{c}\text { Massa } \\
\text { kain } \\
(\mathrm{gram})\end{array}$ & $\begin{array}{c}\mathrm{Xm} / \mathrm{m} / \mathrm{mr}) \\
(\mathrm{mg})\end{array}$ & $\mathrm{Ce} /(\mathrm{Xm} / \mathrm{m})$ \\
\hline 1 & 376,862 & 239,628 & 137,234 & 0,1 & 18,432 & 0,745 & 321,846 \\
2 & 376,862 & 265,904 & 110,957 & 0,1 & 18,764 & 0,591 & 449,670 \\
3 & 376,862 & 292,926 & 83,936 & 0,1 & 18,979 & 0,442 & 662,341 \\
\hline
\end{tabular}

Tabel 5. Data - data untuk Persamaan Langmuir pada Lima Kali Pencelupan untuk Buah Mangrove Jenis Rhizophora stylosa

\begin{tabular}{cccccccc}
\hline No. & $\begin{array}{c}\text { Tanin } \\
\text { awal } \\
(\mathrm{ppm})\end{array}$ & $\begin{array}{c}\text { Tanin } \\
\text { setimbang } \\
(\mathrm{ppm})\end{array}$ & $\begin{array}{c}\text { Tanin } \\
\text { teradsorbsi } \\
(\mathrm{ppm})\end{array}$ & $\begin{array}{c}\mathrm{V} \\
\text { larutan } \\
(\mathrm{L})\end{array}$ & $\begin{array}{c}\text { Massa } \\
\text { kain } \\
(\mathrm{gram})\end{array}$ & $\begin{array}{c}\mathrm{Xm} / \mathrm{m} \\
(\mathrm{mg} / \mathrm{gr})\end{array}$ & $\mathrm{Ce} /(\mathrm{Xm} / \mathrm{m})$ \\
\hline 1 & 376,862 & 239,734 & 137,128 & 0,1 & 17,527 & 0,782 & 306,417 \\
2 & 376,862 & 260,904 & 115,957 & 0,1 & 17,960 & 0,646 & 404,100 \\
3 & 376,862 & 290,266 & 86,596 & 0,1 & 18,079 & 0,479 & 606,002 \\
4 & 376,862 & 313,032 & 63,830 & 0,1 & 18,294 & 0,349 & 897,168 \\
5 & 376,862 & 338,457 & 38,404 & 0,1 & 18,075 & 0,212 & 1592,953 \\
\hline
\end{tabular}

Tabel 6. Data - data untuk Persamaan Langmuir pada Tujuh Kali Pencelupan untuk Buah Mangrove Jenis Rhizophora stylosa

\begin{tabular}{cccccccc} 
No. & $\begin{array}{c}\text { Tanin } \\
\text { awal } \\
(\mathrm{ppm})\end{array}$ & $\begin{array}{c}\text { Tanin } \\
\text { setimbang } \\
(\mathrm{ppm})\end{array}$ & $\begin{array}{c}\text { Tanin } \\
\text { teradsorbsi } \\
(\mathrm{ppm})\end{array}$ & $\begin{array}{c}\mathrm{V} \\
\text { larutan } \\
\text { (L) }\end{array}$ & $\begin{array}{c}\text { Massa } \\
\text { kain } \\
\text { (gram) }\end{array}$ & $\begin{array}{c}\mathrm{Xm} / \mathrm{m} \\
(\mathrm{mg} / \mathrm{gr})\end{array}$ & Ce/(Xm/m) \\
\hline 1 & 376,862 & 241,755 & 135,106 & 0,1 & 17,061 & 0,792 & 305,284 \\
2 & 376,862 & 260,021 & 116,840 & 0,1 & 17,396 & 0,672 & 387,137 \\
3 & 376,862 & 288,883 & 87,979 & 0,1 & 17,409 & 0,505 & 571,634 \\
4 & 376,862 & 310,053 & 66,809 & 0,1 & 17,980 & 0,372 & 834,438 \\
5 & 376,862 & 338,457 & 38,404 & 0,1 & 17,762 & 0,216 & 1565,369 \\
6 & 376,862 & 347,606 & 29,255 & 0,1 & 18,365 & 0,159 & 2182,096 \\
7 & 376,862 & 354,521 & 22,340 & 0,1 & 18,110 & 0,123 & 2873,885 \\
\hline
\end{tabular}

Adsorbsi Zat Warna Alami Buah Mangrove Jenis Rhizophora Stylosa dan Kulit Kayu 


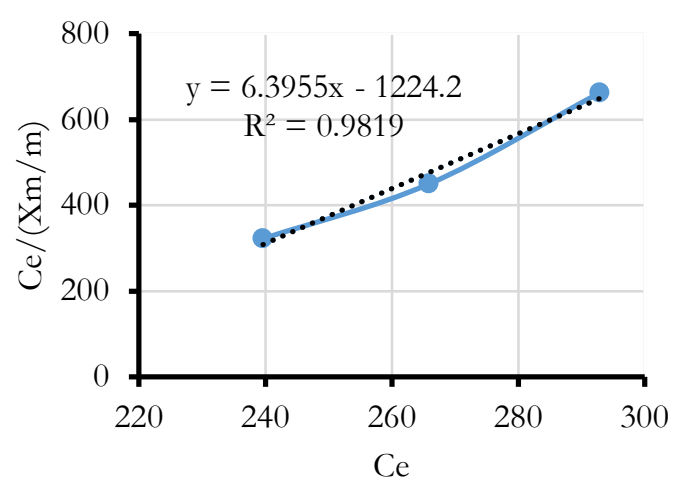

a

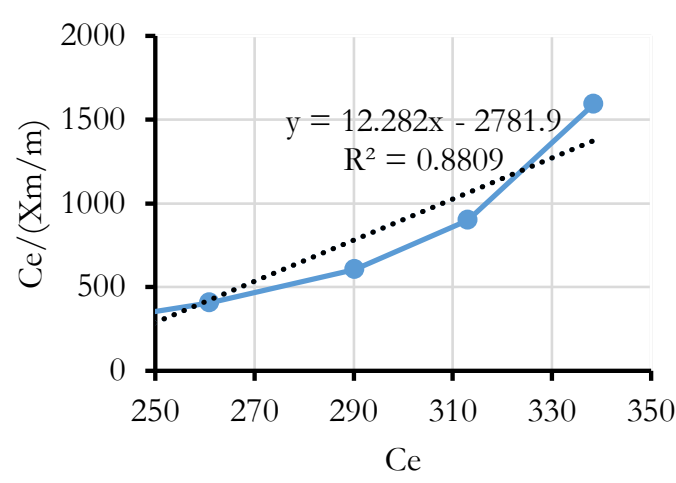

$\mathrm{b}$

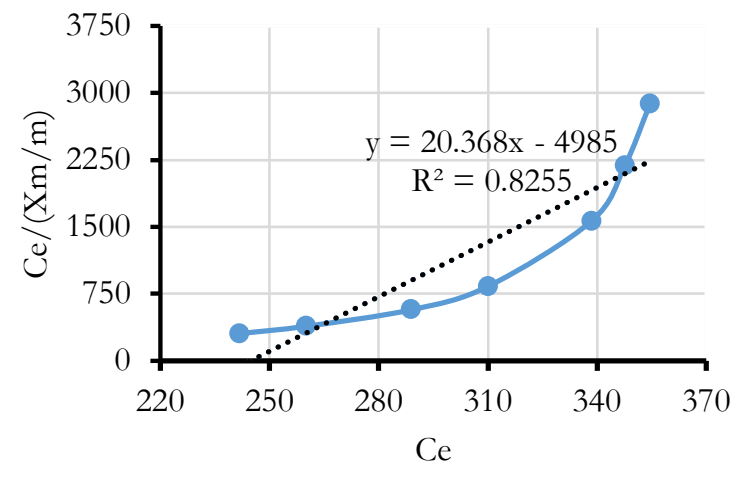

ᄂ

Gambar 3. Tiga Kali Pencelupan (a), Lima Kali Pencelupan (b), Tujuh Kali Pencelupan (c)

Berdasarkan persamaan grafik diatas maka diperoleh untuk tiga kali pencelupan nilai b sebesar $0,15635 \mathrm{mg} / \mathrm{gr}$ dan nilai $\mathrm{k}$ sebesar 0,005224 . Untuk lima kali pencelupan diperoleh nilai b sebesar $0,08141 \mathrm{mg} / \mathrm{gr}$ dan nilai $\mathrm{k}$ sebesar 0,004415 . Untuk tujuh kali pencelupan diperoleh nilai b sebesar $0,04909 \mathrm{mg} / \mathrm{gr}$ dan nilai $\mathrm{k}$ sebesar 0,00408 .

\subsubsection{Model Freundlich}

Model ini digunakan dan disarankan pada anggapan bahwa tidak hanya satu lapisan molekul adsorbat saja yang terserap padatan, sehingga lapisan molekul pada padatan tidak terbatas. Setelah permukaan padatan menyerap satu lapisan molekul adsorbat, maka padatan tersebut membentuk lapisan penyerapan baru dan menyerap adsorbat lainnya. Uji persamaan Freundlich dilakukan dengan menggunakan persamaan 2 [1]:

$$
\log \frac{X m}{m}=\frac{1}{n} \cdot \log C e+\log k
$$

Dengan :

$\mathrm{m}$ : massa kain setelah pencelupan (gram)

Xm : Berat tanin terserap (mg)

$\mathrm{k} \quad$ : kapasitas atau daya adsorpsi maksimum $(\mathrm{mg} / \mathrm{g})$.

n : konstanta adsorpsi

Ce : konsentrasi zat terlarut dalam larutan setelah tercapai kesetimbangan adsorpsi (ppm) 


\subsubsection{Kulit kayu tingi}

Larutan zat warna alami yang telah diketahui konsentrasinya kemudian dimasukkan ke gelas beaker sebanyak $100 \mathrm{~mL}$. Kain dengan berat yang telah ditimbang dimasukkan ke dalam gelas ukur yang sudah terisi $100 \mathrm{~mL}$ larutan zat warna. Setiap pencelupan diambil sampel untuk diuji nilai adsorbansinya sehingga dapat dianalisa konsentrasinya.

Tabel 7 Data - data untuk Persamaan Freundlich Kulit Kayu Tingi pada Tiga Kali Pencelupan

\begin{tabular}{cccccccc}
\hline No. & $\begin{array}{c}\text { Tanin } \\
\text { awal } \\
(\mathrm{ppm})\end{array}$ & $\begin{array}{c}\text { Tanin } \\
\text { setimbang } \\
(\mathrm{ppm})\end{array}$ & $\begin{array}{c}\text { Tanin } \\
\text { teradsorbsi } \\
(\mathrm{ppm})\end{array}$ & $\begin{array}{c}\mathrm{V} \\
\text { larutan } \\
\text { (L) }\end{array}$ & $\begin{array}{c}\text { Massa } \\
\text { kain } \\
(\mathrm{gram})\end{array}$ & $\begin{array}{c}\text { Log } \\
(\mathrm{Xm} / \mathrm{m})\end{array}$ & Log Ce \\
\hline 1 & 418,138 & 253,883 & 164,255 & 0,1 & 17,096 & $-0,017$ & 2,405 \\
2 & 418,138 & 275,904 & 142,234 & 0,1 & 17,622 & $-0,093$ & 2,441 \\
3 & 418,138 & 301,223 & 116,915 & 0,1 & 18,083 & $-0,189$ & 2,479 \\
\hline
\end{tabular}

Tabel 8 Data - data untuk Persamaan Freundlich Kulit Kayu Tingi pada Lima Kali Pencelupan

\begin{tabular}{cccccccc} 
No. & $\begin{array}{c}\text { Tanin } \\
\text { awal } \\
(\mathrm{ppm})\end{array}$ & $\begin{array}{c}\text { Tanin } \\
\text { setimbang } \\
(\mathrm{ppm})\end{array}$ & $\begin{array}{c}\text { Tanin } \\
\text { teradsorbsi } \\
(\mathrm{ppm})\end{array}$ & $\begin{array}{c}\mathrm{V} \\
\text { larutan } \\
(\mathrm{L})\end{array}$ & $\begin{array}{c}\text { Massa } \\
\text { kain } \\
(\mathrm{gram})\end{array}$ & $\begin{array}{c}\text { Log } \\
\text { (Xm/m) }\end{array}$ & Log Ce \\
\hline 1 & 418,138 & 253,883 & 164,255 & 0,1 & 17,434 & $-0,026$ & 2,405 \\
2 & 418,138 & 275,904 & 142,234 & 0,1 & 17,793 & $-0,097$ & 2,441 \\
3 & 418,138 & 301,223 & 116,915 & 0,1 & 18,036 & $-0,188$ & 2,479 \\
4 & 418,138 & 338,245 & 79,894 & 0,1 & 18,638 & $-0,368$ & 2,529 \\
5 & 418,138 & 367,606 & 50,532 & 0,1 & 18,730 & $-0,569$ & 2,565 \\
\hline
\end{tabular}

Tabel 9 Data - data untuk Persamaan Freundlich Kulit Kayu Tingi pada Tujuh Kali Pencelupan

\begin{tabular}{cccccccc}
\hline No. & $\begin{array}{c}\text { Tanin } \\
\text { awal } \\
(\mathrm{ppm})\end{array}$ & $\begin{array}{c}\text { Tanin } \\
\text { setimbang } \\
(\mathrm{ppm})\end{array}$ & $\begin{array}{c}\text { Tanin } \\
\text { teradsorbsi } \\
(\mathrm{ppm})\end{array}$ & $\begin{array}{c}\text { V } \\
\text { larutan } \\
(\mathrm{L})\end{array}$ & $\begin{array}{c}\text { Massa } \\
\text { kain } \\
\text { (gram) }\end{array}$ & $\begin{array}{c}\text { Log } \\
\text { (Xm/m) }\end{array}$ & Log Ce \\
\hline 1 & 418,138 & 253,883 & 164,255 & 0,1 & 17,183 & $-0,020$ & 2,405 \\
2 & 418,138 & 275,904 & 142,234 & 0,1 & 17,722 & $-0,096$ & 2,441 \\
3 & 418,138 & 301,223 & 116,915 & 0,1 & 18,105 & $-0,190$ & 2,479 \\
4 & 418,138 & 338,245 & 79,894 & 0,1 & 18,691 & $-0,369$ & 2,529 \\
5 & 418,138 & 367,606 & 50,532 & 0,1 & 18,558 & $-0,565$ & 2,565 \\
6 & 418,138 & 376,862 & 41,277 & 0,1 & 19,172 & $-0,667$ & 2,576 \\
7 & 418,138 & 389,734 & 28,404 & 0,1 & 19,071 & $-0,827$ & 2,591 \\
\hline
\end{tabular}

Adsorbsi Zat Warna Alami Buah Mangrove Jenis Rhizophora Stylosa dan Kulit Kayu 


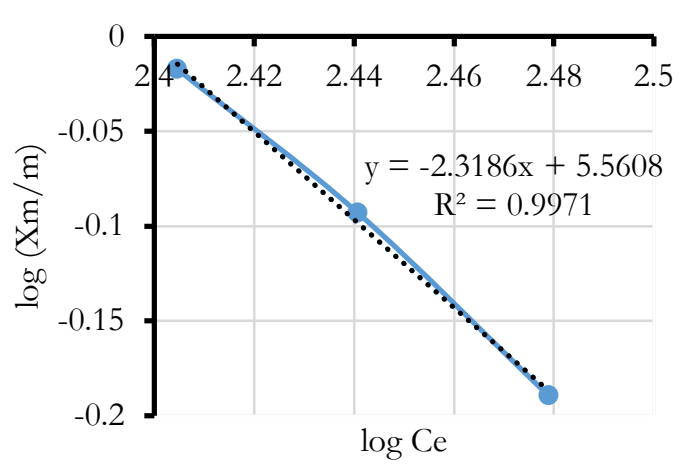

a.

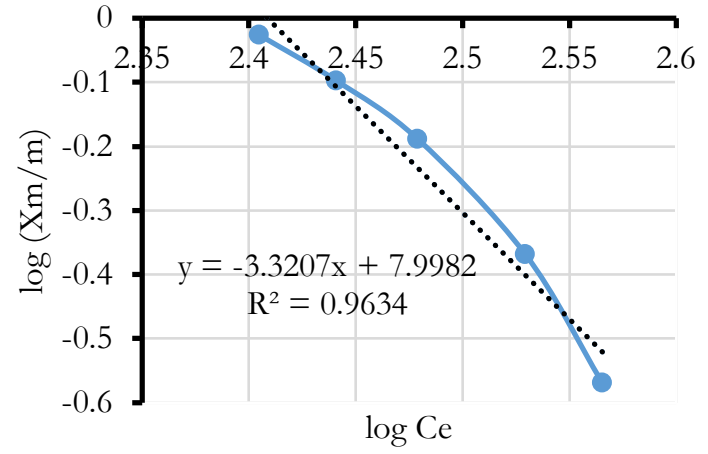

$\mathrm{b}$

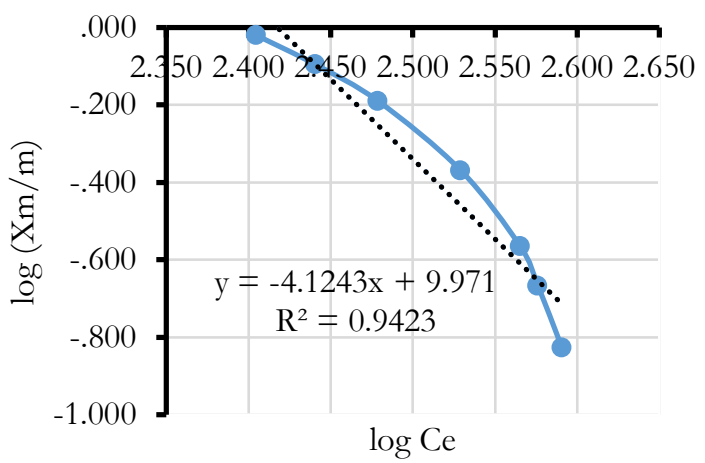

c.

Gambar 4. Tiga Kali Pencelupan (a), Lima Kali Pencelupan (b), Tujuh Kali Pencelupan (c)

Berdasarkan persamaan grafik diatas untuk tiga kali pencelupan diperoleh nilai $\mathrm{n}$ sebesar 0,4312 dan nilai $\mathrm{k}$ sebesar $0,36374 \times 10^{3} \mathrm{mg} / \mathrm{g}$. Untuk lima kali pencelupan diperoleh nilai $\mathrm{n}$ sebesar 0,30114 dan nilai $\mathrm{k}$ sebesar $0,99586 \times 10^{5} \mathrm{mg} / \mathrm{g}$. Untuk tujuh kali pencelupan diperoleh nilai $\mathrm{n}$ sebesar 0,2424 dan nilai $\mathrm{k}$ sebesar 0,9354 $\mathrm{x} 10^{7} \mathrm{mg} / \mathrm{g}$.

\subsubsection{Buah Mangrove Jenis Rhizophora Stylosa}

Larutan zat warna alami yang telah diketahui konsentrasinya kemudian dimasukkan ke gelas beaker sebanyak $100 \mathrm{~mL}$. Kain dengan berat yang telah ditimbang dimasukkan ke dalam gelas ukur yang sudah terisi $100 \mathrm{~mL}$ larutan zat warna. Setiap pencelupan diambil sampel untuk diuji nilai adsorbansinya sehingga dapat dianalisis konsentrasinya.

Tabel 10. Data - data untuk Persamaan Freundlich Buah Mangrove jenis Rhyzophora Stylosa Pada Tiga Kali Pencelupan

\begin{tabular}{cccccccc} 
No. & $\begin{array}{c}\text { Tanin } \\
\text { awal } \\
(\mathrm{ppm})\end{array}$ & $\begin{array}{c}\text { Tanin } \\
\text { setimbang } \\
(\mathrm{ppm})\end{array}$ & $\begin{array}{c}\text { Tanin } \\
\text { teradsorbsi } \\
(\mathrm{ppm})\end{array}$ & $\begin{array}{c}\text { V } \\
\text { larutan } \\
\text { (L) }\end{array}$ & $\begin{array}{c}\text { Massa } \\
\text { kain } \\
(\mathrm{gram})\end{array}$ & $\begin{array}{c}\text { Log } \\
(\mathrm{Xm} / \mathrm{m})\end{array}$ & Log Ce \\
\hline 1 & 376,862 & 239,628 & 137,234 & 0,1 & 18,432 & $-0,128$ & 2,380 \\
2 & 376,862 & 265,904 & 110,957 & 0,1 & 18,764 & $-0,228$ & 2,425 \\
3 & 376,862 & 292,926 & 83,936 & 0,1 & 18,979 & $-0,354$ & 2,467 \\
\hline
\end{tabular}


Tabel 11 Data - data untuk Persamaan Freundlich Buah Mangrove jenis Rhizophora Stylosa pada Lima Kali Pencelupan

\begin{tabular}{cccccccc}
\hline No. & $\begin{array}{c}\text { Tanin } \\
\text { awal } \\
(\mathrm{ppm})\end{array}$ & $\begin{array}{c}\text { Tanin } \\
\text { setimbang } \\
(\mathrm{ppm})\end{array}$ & $\begin{array}{c}\text { Tanin } \\
\text { teradsorbsi } \\
(\mathrm{ppm})\end{array}$ & $\begin{array}{c}\mathrm{V} \\
\text { larutan } \\
(\mathrm{L})\end{array}$ & $\begin{array}{c}\text { Massa } \\
\text { kain } \\
(\mathrm{gram})\end{array}$ & $\begin{array}{c}\text { Log } \\
\text { (Xm/m) }\end{array}$ & Log Ce \\
\hline 1 & 376,862 & 239,734 & 137,128 & 0,1 & 17,527 & $-0,107$ & 2,380 \\
2 & 376,862 & 260,904 & 115,957 & 0,1 & 17,960 & $-0,190$ & 2,416 \\
3 & 376,862 & 290,266 & 86,596 & 0,1 & 18,079 & $-0,320$ & 2,463 \\
4 & 376,862 & 313,032 & 63,830 & 0,1 & 18,294 & $-0,457$ & 2,496 \\
5 & 376,862 & 338,457 & 38,404 & 0,1 & 18,075 & $-0,673$ & 2,530 \\
\hline
\end{tabular}

Tabel 12 Data - data untuk Persamaan Freundlich Buah Mangrove jenis Rbirophora Stylosa pada Tujuh Kali Pencelupan

\begin{tabular}{cccccccc} 
No. & $\begin{array}{c}\text { Tanin } \\
\text { awal } \\
(\mathrm{ppm})\end{array}$ & $\begin{array}{c}\text { Tanin } \\
\text { setimbang } \\
(\mathrm{ppm})\end{array}$ & $\begin{array}{c}\text { Tanin } \\
\text { teradsorbsi } \\
(\mathrm{ppm})\end{array}$ & $\begin{array}{c}\text { V } \\
\text { larutan } \\
(\mathrm{L})\end{array}$ & $\begin{array}{c}\text { Massa } \\
\text { kain } \\
\text { (gram) }\end{array}$ & $\begin{array}{c}\text { Log } \\
\text { (Xm/m) }\end{array}$ & Log Ce \\
\hline 1 & 376,862 & 241,755 & 135,106 & 0,1 & 17,061 & $-0,101$ & 2,383 \\
2 & 376,862 & 260,021 & 116,840 & 0,1 & 17,396 & $-0,173$ & 2,415 \\
3 & 376,862 & 288,883 & 87,979 & 0,1 & 17,409 & $-0,296$ & 2,461 \\
4 & 376,862 & 310,053 & 66,809 & 0,1 & 17,980 & $-0,430$ & 2,491 \\
5 & 376,862 & 338,457 & 38,404 & 0,1 & 17,762 & $-0,665$ & 2,530 \\
6 & 376,862 & 347,606 & 29,255 & 0,1 & 18,365 & $-0,798$ & 2,541 \\
7 & 376,862 & 354,521 & 22,340 & 0,1 & 18,110 & $-0,909$ & 2,550 \\
\hline
\end{tabular}

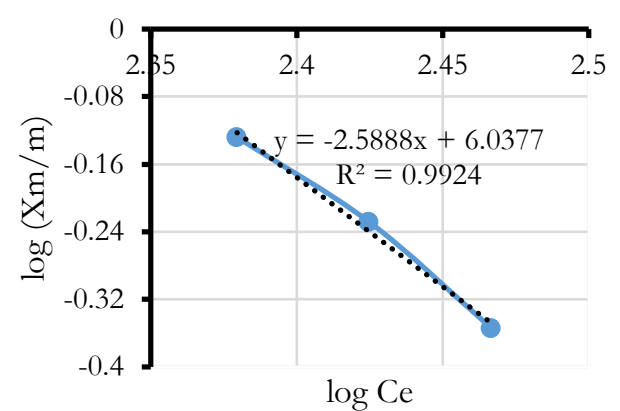

a.

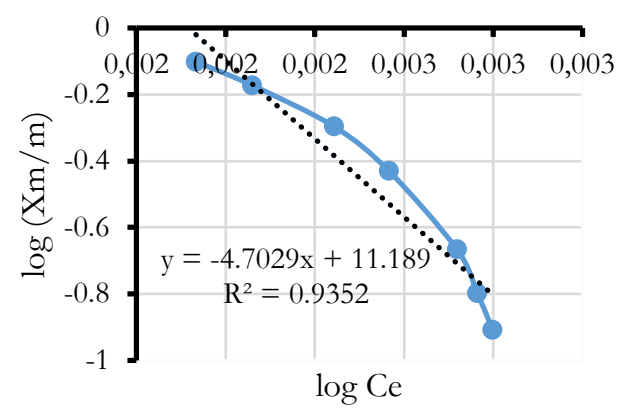

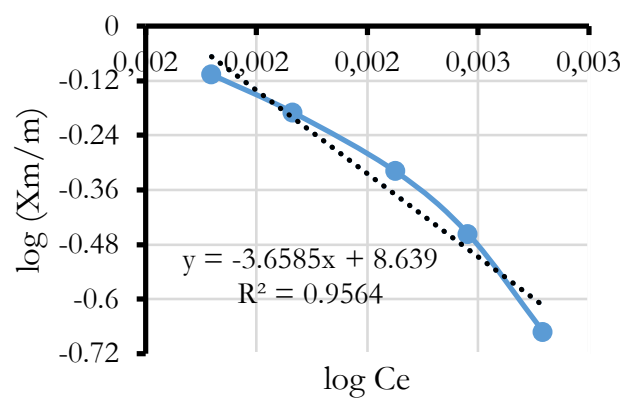

b.

c.

Gambar 5. Tiga Kali Pencelupan (a), Lima Kali Pencelupan (b), Tujuh Kali Pencelupan (c)

Adsorbsi Zat Warna Alami Buah Mangrove Jenis Rhizophora Stylosa dan Kulit Kayu 
Berdasarkan persamaan grafik diatas untuk tiga kali pencelupan diperoleh nilai $\mathrm{n}$ sebesar 0,3862 dan nilai $\mathrm{k}$ sebesar $0,1090 \times 10^{4} \mathrm{mg} / \mathrm{g}$. Untuk lima kali pencelupan diperoleh nilai $\mathrm{n}$ sebesar 0,2733 dan nilai $\mathrm{k}$ sebesar $0,4355 \times 10^{6} \mathrm{mg} / \mathrm{g}$. Untuk tujuh kali pencelupan diperoleh nilai n sebesar 0,2126 dan nilai k sebesar 0,1545 x $10^{9} \mathrm{mg} / \mathrm{g}$.

\subsection{Perbandingan nilai konstanta kesetimbangan adsorbsi}

Pemilihan dalam menentukan persamaan didasarkan pada nilai kesalahan dari hasil perhitungan persamaan tersebut. Hal ini akan mempengaruhi nilai konstanta kesetimbangan adsorbsi.yang didapatkan.

Data hasil perhitungan konstanta kesetimbangan ditunjukkan pada tabel berikut :

\begin{tabular}{ccccc} 
Jumlah & \multicolumn{2}{c}{ Kulit Kayu Tingi } & \multicolumn{2}{c}{ Rhizopora Stylosa } \\
Pencelupan & Langmuir & Freundlich & Langmuir & Freundlich \\
\hline 3 & 0,00517 & 0,4312 & 0,005224 & 0,3862 \\
5 & 0,00421 & 0,30114 & 0,004415 & 0,2733 \\
7 & 0,003899 & 0,2424 & 0,00408 & 0,2126 \\
\hline
\end{tabular}

Dari grafik sebelumnya menunjukkan bahwa nilai R persamaan Freundlich lebih mendekati angka 1 dibandingkan pada persamaan Langmuir. Hal ini menunjukkan bahwa penggunaan persamaan Freundlich dalam penentuan konstanta kesetibangan adsorbsi pada zat warna alami kulit kayu tingi dan rbižbopora stylosa lebih baik daripada persamaan Langmuir.

\subsection{Perubahan warna setelah proses fiksasi}

Untuk memperoleh zat warna dengan ketahanan luntur yang baik maka perlu dilakukan proses fiksasi atau penguncian. Fiksasi merupakan proses pencelupan yang bertujuan untuk mengunci zat warna yang masuk ke dalam serat agar warna yang dihasilkan tidak mudah pudar atau luntur. Fiksasi dilakukan dengan menambahkan bahan yang mengandung kompleks logam. Bahan fiksasi yang biasa digunakan antara lain kapur, tawas, dan tunjung [13]. Berikut adalah hasil dari proses fiksasi kain kedalam larutan tunjung dan tawas.

\begin{tabular}{|c|c|c|c|c|}
\hline \multirow{2}{*}{ Pewarna } & \multicolumn{2}{|c|}{ Tunjung } & \multicolumn{2}{|c|}{ Tawas } \\
\hline & Sebelum & Sesudah & Sebelum & Sesudah \\
\hline Kulit Kayu Tingi & & & & \\
\hline Rhyzopora & & & & \\
\hline Stylosa & & & & \\
\hline
\end{tabular}

Perubahan warna dari proses fiksasi pada ekstrak kulit tingi dengan tawas adalah dari warna coklat menjadi hitam, sedangkan dengan tawas dari warna coklat menjadi coklat tua. Perubahan warna dari proses fiksasi pada ekstrak Rhizopora stylosa dengan tunjung adalah dari warna coklat menjadi coklat keabu-abuan, sedangkan dengan tawas adalah dari warna coklat menjadi coklat tua. 


\section{Kesimpulan}

Penentuan nilai konstanta kesetimbangan adsorpsi kain terhadap zat warna alami Rhizopora stylosa dan kulit kayu tingi yang paling sesuai adalah dengan menggunakan persamaan adsorpsi Freundlich dibandingkan dengan persamaan Langmuir. Hal ini dibuktikan dengan nilai kesalahan persamaan Freundlich yang lebih kecil dibandingkan persamaan Langmuir dengan ditunjukkan nilai $\mathrm{R}^{2}$ yang mendekati angka 1. Nilai konstanta kesetimbangan adsorbsi persamaan Langmuir kayu tingi untuk tiga kali, lima kali dan tujuh kali pencelupan adalah 0,00517, 0,00421 dan 0,003899. Sedangkan pada persamaan Freundlich nilai kesetimbangan adsorbsi kayu tingi untuk tiga kali, lima kali dan tujuh kali pencelupan adalah 0,4312, 0,30114 dan 0,2424. Nilai konstanta kesetimbangan adsorbsi persamaan Langmuir Rhizopora stylosa untuk tiga kali, lima kali dan tujuh kali pencelupan adalah 0,005224, 0,004415 dan 0,00408. Sedangkan pada persamaan Freundlich Rhizopora stylosa nilai konstanta kesetimbangan adsorbsi untuk tiga kali, lima kali dan tujuh kali pencelupan adalah 0,3862, 0,2733 dan 0,2126. Dapat disimpulkan bahwa semakin banyak pencelupan maka semakin kecil daya serap kain terhadap tanin.

Perubahan warna dari proses fiksasi pada zat warna kulit tingi dengan tunjung adalah dari warna coklat menjadi hitam, sedangkan dengan tawas dari warna coklat menjadi coklat tua. Perubahan warna dari proses fiksasi pada zat warna Rhizopora stylosa dengan tunjung adalah dari warna coklat menjadi coklat keabu-abuan, sedangkan dengan tawas adalah dari warna coklat menjadi coklat tua.

\section{References}

[1] Amanda, Dea. 2020. Uji Persamaan Langmuir Dan Freundlich Pada Penyerapan Ion Logam Kobalt (II) Oleh Kitosan dari Kulit Udang Windu. Aceh : Fakultas Sains dan Teknologi, UIN Ar-Raniry Aceh.

[2] Hamidah , 2006. Rendemen dan Kadar Tanin Kulit Kayu Bakau (Rhizophora Mucronata Lamck) dari Daerah Takisung. Banjarbaru : Jurusan Manajemen Hutan Universitas Lambung Mangkurat,Banjarbaru

[3] Handayani, P., Ramadhani, N., \& Kartika, D. (2018). Pemungutan tanin propagul mangrove(rhizopora mucronata) dengan pelarut etanol dan aquades sebagai zat warna alami menggunakan metode microwave assisted extraction. Jurnal Kompetensi Teknik. Vol. 10. No.1.

[4] Jansen, P. C. M. et al. 2005. Prota 3: Dyes and tannins. Netherland: Wageningen.

[5] Kalsum,Ummi. 2015. Pemanfaatan Eceng Gondok Sebagai Zat Penyerap Warna Pada Limbah Industri Tekstil Sebagai Upaya Mengurangi Pencemaran Air. Palembang : Program Studi Teknik Kimia Fakultas Teknik Universitas Muhammadiyah Palembang.

[6] Kartikasari, E., \& Susiati, Y. T.(2016). Pengaruh FIiksator pada Ekstrak Daun Mangga Dalam Pewarnaan Tekstil Batik Ditinjau dari Ketahanan Luntur Warna Terhadap Keringat. Jurnal SCIENTECH, 2(1), 136-143.

[7] Kementrian Lingkungan Hidup dan Kehutanan. www.ppid.menlhk.go.id/berita/beritafoto/580/miliki-23-ekosistem-mangrove-dunia-indonesia-tuan-rumah-konferensi-internasionalmangrove-2017. (Diakses 12 Januari 2021).

[8] Kementrian Perindustrian. www.kemenperin.go.id/artikel/21191/Industri-Tekstil-dan-PakaianTumbuh-Paling-Tinggi (Diakses 20 Maret 2021).

[9] Lutfianna, dkk. 2018. Pemanfaatan Mangrove Rhizopora Muncorata Sebagai Pewarna Alami Kain Katun. Semarang: Departemen Ilmu Kelautan, Universitas Diponegoro.

[10] Mukhriani, dkk. 2014. Penetapan Kadar Tanin Total Ekstrak Biji Jintan Hitam (Nigella Sativa) Secara Spektrofotometri UV-VIS. Makassar: Jurusan Farmasi Fakultas Ilmu Kesehatan Universitas Islam Negeri Alauddin Makassar.

[11] Noer, Shafa, dkk. 2018. Penetapan Kadar Senyawa Fitokimia (Tanin, Saponin Dan Flavonoid Sebagai Kuersetin) pada Ekstrak Daun Inggu (Ruta angustifolia L.) Jakarta: Universitas Indraprasta PGRI Jakarta.

[12] Paryanto, dkk. 2016. Pembuatan Zat Warna Alami dari Buah Mangrove Spesies Rhizopora Stylosa Sebagai Pewarna Batik Ramah Lingkungan Dalam Skala Pilot Plan. Surakarta: Program Studi Teknik Kimia, Fakultas Teknik, UNS.

Adsorbsi Zat Warna Alami Buah Mangrove Jenis Rhizophora Stylosa dan Kulit Kayu 
[13] Rizka, dkk. 2016. Studi Pengaruh Jenis Dan Konsentrasi Zat Fiksasi Terhadap Kualitas Warna Kain Batik Dengan Pewarna Alam Limbah Kulit Buah Rambutan (Nephelium Lappaceum). Pekalongan : Program Studi D3 Teknik Batik Politeknik Pusmanu Pekalongan.

[14] Soenardjo, N., \& Supriyantini (2017). Analisis Kadar Tanin Dalam Buah Mangrove Avicennia marinaDengan Perebusan Dan Lama Perendaman Air Yang Berbeda. Semarang: Departemen Ilmu Kelautan, Fakultas Perikanan dan Ilmu Kelautan, Universitas Diponegoro. Vol. 20(2).

[15] Tanadi, K., \& Kusmartono, B. (2019). Optimasi Kondisi Proses Pengambilan Tanin dari Pinang. Yogyakarta: Jurusan Teknik Kimia, Institut Sains \& Teknologi AKPRIND. Vol. 4. No 1.

[16] Yernisa, Gumbira-Sadid, E., \& Syamsu, K. (2013). Aplikasi Pewarna Bubuk Alami dari Ekstrak Biji Pinang (Areca catechu L.) pada Pewarnaan Sabun Transparan. Jurnal Teknologi Industri Pertanian, 23 (3), $190 \pm 198$.

[17] Zulfa, F., \& Wijayanti, I. (2016). Pengaruh "Soga tingi”(Cerios tagal) sebagai Bahan Penyamak Terhadap Kualitas Fisik dan Kimia Kulit Ikan Bandeng (Chanos chanosForsk). Semarang: Program Studi Teknologi Hasil Perikanan, Jurusan Perikanan, Fakultas Perikanan dan Ilmu Kelautan, Universitas Diponegoro. Vol. 5(1). 